\title{
FAKTOR-FAKTOR YANG MEMPENGARUHI KEPATUHAN IBU DALAM PEMANFAATAN POSYANDU DI WILAYAH KERJA PUSKESMAS MENTENG KOTA PALANGKA RAYA
}

\section{The Factors Affecting Maternal Compliance in Utilizing Posyandu in the Work Area of Menteng Public Health Center, Palangka Raya City}

\section{Nita Theresia ${ }^{1 *}$ \\ Rikiy ${ }^{2}$ \\ *Jurusan Keperawatan \\ Politeknik Kesehatan \\ Kemenkes, Palangka Raya, \\ kalimantan Tengah, Indonesia \\ 2Jurusan Keperawatan \\ Politeknik Kesehatan \\ Kemenkes, Palangka Raya, \\ kalimantan Tengah, Indonesia \\ *email: nitathere@gmail.com}

\begin{abstract}
Abstrak
Angka capaian Kalimantan Tengah di beberapa indikator kesehatan masyarakat berada di bawah capaian nasional seperti cakupan imunisasi Td2+ (46,2\%), cakupan pelayanan ibu nifas $(76,75 \%)$, cakupan imunisasi dasar lengkap $(87,3 \%)$ dan prevalensi anak kurus (10,6\%) dan stunting (39\%). Pemanfaatan pelayanan kesehatan terutama posyandu yang masih belum optimal yang berdampak pada banyaknya balita yang mengalami gizi buruk dan cakupan beberapa kegiatan posyandu yang masih berada di bawah angka capaian nasional. Rancangan penelitian yang digunakan adalah observasional analitik dengan menggunakan pendekatan metode cross sectional. Subjek pada penelitian ini adalah semua ibu yang datang ke Posyandu yang dipilih dengan teknik total sampling. Dari hasil analisis univariat paling banyak ibu yang aktif memanfaatkan pelayanan di posyandu adalah ibu yang berada di rentang usia $20-35$ tahun yaitu sebesar $55 \%$, pendidikan terakhir SMA yaitu sebanyak $40 \%$, ibu yang memiliki balita dan tidak bekerja $85 \%$, jarak yang terjangkau $90 \%$, dan tidak rutin melakukan kunjungan ke posyandu $87,5 \%$. Berdasarkan analisi bivariat, tidak ditemukannya variabel tidak terikat (usia, pendidikan, pekerjaan dan jarak) yang menunjukkan pengaruh terhadap pemanfaatan pelayanan posyandu.
\end{abstract}

Kata Kunci:

Kepatuhan Ibu

Posyandu

Usia

Pendidikan

Pekerjaan

\section{Keywords:}

Maternal Compliance

Posyandu

Age

Education

Work

\begin{abstract}
Central Kalimantan achievement rate in several public health indicators is below the national achievement such as $T d 2+$ immunization coverage (46.2\%), postpartum maternity service coverage $(76.75 \%)$, complete basic immunization coverage (87.3\%) and prevalence of lean children (10.6\%) and stunting (39\%). Utilization of health services, especially posyandu, is still not optimal, which has an impact on the number of children under five suffering from malnutrition and the coverage of several posyandu activities that are still below the national achievement rate. The research design used was observational analytic using a crosssectional approach. The subjects in this study were all mothers who came to posyandu who were selected by total sampling technique. From the results of univariate analysis, most mothers who actively use services at posyandu are mothers who are in the age range of 2035 years, amounting to $55 \%$, the last high school education is as much as $40 \%$, mothers who have toddlers and not working $85 \%$, affordable distance $90 \%$, and non-routine visits to posyandu $87.5 \%$. Based on bivariate analysis, no independent variables (age, education, occupation and distance) were found which showed the influence on the use of posyandu services.
\end{abstract}

(C) year The Authors. Published by Institute for Research and Community Services Universitas Muhammadiyah Palangkaraya. This is Open Access article under the CC-BY-SA License (http://creativecommons.org/licenses/by-sa/4.0/). DOI: https://doi.org//0.33084/jsm.vxix.xxx.

\section{PENDAHULUAN}

Tujuan pembangunan nasional yang tercantum dalam konsep Rencana Pembangunan Jangka Panjang Nasional (RPJMN) 2015-2019 salah satunya adalah peningkatan kualitas sumber daya manusia (SDM). Upaya peningkatan kualitas SDM dimulai dengan proses tumbuh kembang anak sejak pembuahan sampai usia dewasa muda. Salah satu upaya perilaku kesehatan adalah perilaku masyarakat yang datang ke posyandu (Sugiyarti dkk, 20l4; Fitriani dkk, 20l6).

Posyandu merupakan tempat yang paling cocok untuk memberikan pelayanan kesehatan pada balita dan ibu secara menyeluruh dan terpadu. Posyandu dikelola dan 
Nita Theresia, Rikiy. 2020. The Factors Affecting Maternal Compliance in Utilizing Posyandu in the Work Area of Menteng Public Health Center, Palangka Raya City

diselenggarakan dari, oleh, untuk dan bersama masyarakat dalam penyelenggaraan pembangunan kesehatan, guna memberdayakan masyarakat dan memberikan kemudahan kepada masyarakat dalam memperoleh pelayanan kesehatan dasar. Posyandu menyelenggarakan minimal 5 program prioritas, yaitu kesehatan ibu dan anak, keluarga berencana, perbaikan gizi, imunisasi dan penanggulangan diare. Untuk memantau perkembangannya posyandu dikelompokan menjadi 4 strata, yaitu posyandu pratama, posyandu madya, posyandu purnama dan posyandu mandiri (Idaningsih, 2016; Rita, 2016; Dinas Kesehatan Provinsi Kalimantan Tengah, 2017).

Berdasarkan profil kesehatan yang dirilis Kementerian Kesehatan jumlah posyandu di Kalimantan Tengah tahun 2016 adalah 2410 unit, lebih banyak bila dibandingkan tahun 2015 sebanyak 2340 unit. Rincian posyandu berdasarkan stratanya pada tahun 2016 adalah sebagai berikut; Posyandu Pratama 909 unit(37.72\%), Posyandu Madya II09 unit (46.02\%), Posyandu Purnama 326 unit (13.53\%) dan Posyandu Mandiri 66 unit (2,74\%). Sedangkan Posyandu yang masuk kategori aktif sebanyak 392 unit (16,27\%). Ada sedikit penurunan jumlah posyandu yang aktif bila dibandingkan dengan jumlah posyandu aktif pada tahun 2015 (Dinas Kesehatan Provinsi Kalimantan Tengah, 2017).

Profil kesehatan 2017 yang dirilis kementerian kesehatan memperlihatkan angka capaian Kalimantan Tengah dibeberapa indikator berada di bawah capaian nasional. Berdasarkan cakupan pelayanan kesehatan ibu hamil K4 mencapai angka 83,88\%, angka ini lebih rendah dari angka capaian nasional sebesar $87,30 \%$. Pada pelayanan imunisasi Td5 pada wanita subur, Kalimantan Tengah termasuk dalam provinsi lima terendah denga angka yang baru menyentuh $0.56 \%$, angka ini jauh lebih rendah dari capaiaan nasional yang sebesar 2,40\%. Angka cakupan imunisasi Td2+ pada ibu hamil sebesar 46,20\%, angka ini lebih rendah dari capaiaan nasional sebesar $65,30 \%$. Sedangkan untuk cakupan pelayan ibu nifas (KF3) sebesar 76,75\%, meskipun sudah cukup tinggi namun masih berada dibawah capaiaan nasional sebesar 87,36\%. Pada cakupan peserta KB aktif menurut kontrasepsi modern Kalimantan Tengah menempati posisi lima terbawah dengan angka cakupan sebesar 7,48\%. Cakupan ibu hamil KEK yang mendapat makanan tambahan hanya mencapai angka 63,08\%, angka ini jauh dibawah pencapaiaan nasional yang sebesar 82,83\% (Kementerian Kesehatan Republik Indonesia, 2018).

Cakupan imunisasi dasar lengkap pada bayi menunjukkan angka 87,3\%, jika dibandingkan dengan capaian nasional sebesar 91\%, provinsi Kalimantan Tengah masih lebih rendah. Pada cakupan pemberian kapsul vitamin A pada balita juga meskipun sudah mencapai angka 92,78 masih berada dibawah angka capaian nasional yang mencapai 94,73\% (Kementerian Kesehatan Republik Indonesia, 2018).

Angka prevalensi kejadian anak kurus dan sangat kurus juga menunjukkan angka yang tinggi yaitu sebesar 10,6\%, jika dibandingkan angka prevalensi nasional sebesar 9,5\%. Angka prevalensi kejadian stunting pada anak provinsi Kalimantan Tengah masuk dalam tiga tertinggi dengan angka prevalensi 39\%. Sedangkan angka prevalensi gizi buruk dan kurang pada anak 0-59 bulan termasuk dalam sepuluh provinsi tertinggi dengan angka 23,6\% (Kementerian Kesehatan Republik Indonesia, 2018).

Berdasarkan data di atas dapat disimpulkan bahwa pemanfaatan pelayanan kesehatan terutama posyandu di provinsi Kalimantan Tengah masih belum optimal yang berdampak pada banyaknya balita yang mengalami gizi buruk dan cakupan beberapa kegiatan posyandu yang masih berada di bawah angka capaiaan nasional.

\section{METODOLOGI}

Rancangan penelitian yang digunakan adalah observasional analitik dengan menggunakan 
pendekatan metode cross sectional. Subjek pada penelitian ini adalah semua ibu yang datang ke Posyandu yang dipilih dengan teknik total sampling. Instrumen penelitian yang digunakan pada penelitian ini yaitu lembar kuesioner. Varianel bebas dalam penelitian ini adalah usia, pendidikan, pekerjaan, dan jarak tempuh ke pelayanan posyandu. Sedangkan variabel terikat pada penelitian ini adalah kepatuhan ibu. Analisis data secara univariat dan bivariat dengan uji menggunakan uji spearman rank dengan tingkat kepercayaan $95 \%$.

\section{HASIL DAN PEMBAHASAN}

Tabel I Distribusi frekuensi responden yang memanfaatkan pelayanan di posyandu

\begin{tabular}{|c|c|c|}
\hline Variabel & Frekuensi & Persentase (\%) \\
\hline \multicolumn{3}{|l|}{ Umur } \\
\hline$<20$ Tahun & $\mathrm{I}$ & 2,5 \\
\hline $20-35$ Tahun & 22 & 55 \\
\hline$>35$ Tahun & 17 & 42,5 \\
\hline \multicolumn{3}{|l|}{ Pendidikan } \\
\hline SD & 9 & 22,5 \\
\hline SMP & 7 & 17,5 \\
\hline SMA & 16 & 40 \\
\hline Perguruan Tinggi & 8 & 20 \\
\hline \multicolumn{3}{|l|}{ Pekerjaan } \\
\hline Bekerja & 6 & 25 \\
\hline Tidak Bekerja & 34 & 85 \\
\hline \multicolumn{3}{|l|}{ Jarak } \\
\hline$<\mathrm{I} \mathrm{Km}$ & 36 & 90 \\
\hline$>\mathrm{I} \mathrm{Km}$ & 4 & 10 \\
\hline \multicolumn{3}{|l|}{ Kepatuhan } \\
\hline Tidak Patuh & 35 & 87,5 \\
\hline Patuh & 5 & 12,5 \\
\hline
\end{tabular}

Tabel 2 Analisis variabel bebas terhadap kepatuhan memanfaatkan pelayanan di posyandu

\begin{tabular}{lll}
\hline Variabel & P-value & Correlation \\
& & Chi-square
\end{tabular}

Usia Terhadap Kepatuhan Ibu

$0,325 \quad 2,614$

\begin{tabular}{lcc}
\hline $\begin{array}{l}\text { Pendidikan Terhadap Kepatuhan } \\
\text { Ibu }\end{array}$ & $0,6 \mathrm{II}$ & $\mathrm{I,8I9}$ \\
\hline $\begin{array}{l}\text { Pekerjaan Terhadap Kepatuhan } \\
\text { Ibu }\end{array}$ & 0,264 & $\mathrm{I}, 264$ \\
& & \\
\hline Jarak Terhadap Kepatuhan Ibu & 0,376 & 0,784
\end{tabular}

Berdasarkan tabel 2 didapatkan hasil bahwa semua variabel tidak terikat (usia, pendidikan, pekerjaan dan jarak) dengan pergaruhnya terhadap kepatuhan memilikin nilai lebih besar dari alfa $(>0,05)$, sehingga $\mathrm{H}_{0}$ ditolak membuat semua variabel tidak terikat tidak memiliki pengaruh terhadap kepatuhan ibu dalam memanfaatkan pelayanan posyandu.

Hasil penelitian ini berbanding terbalik dengan penelitian yang dilakukan Rita (2016), dimana penelitian tersebut menemukan adanya pengaruh antara pendidikan dengan pemanfaatan posyandu. Berdasarkan dalam penelitian tersebut, ibu yang memiliki pendidikan tinggi memanfaatkan Posyandu dengan baik sebanyak $82,9 \%$, pada responden yang berpendidikan tinggi memanfaatkan Posyandu dengan kurang baik sebanyak 17,1\%. Sedangkan pada responden yang berpendidikan rendah memanfaatkan Posyandu baik sebanyak 59,2\% dan pada responden berpendidikan rendah memanfaatkan Posyandu dengan kurang baik sebanyak 40,8\% (Rita, 2016). Penelitian Rita ini didukung dengan hasil penelitian yang dilakukan Dinengsih, dkk (2018) yang menemukan hubungan bermakna antara tingkat pendidikan dengan kepatuhan ibu dalam melakukan imunisasi dasar.

Pada variabel pekerjaan, hasil penelitian ini juga berbanding terbalik dengan penelitian Rita (2016), yang menyatakan bahwa ada hubungan yang bermakna antara pekerjaan dengan pemanfaatan Posyandu Melati III. Penelitian tersebut menyebutkan bahwa responden 
Nita Theresia, Rikiy. 2020. The Factors Affecting Maternal Compliance in Utilizing Posyandu in the Work Area of Menteng Public Health Center, Palangka Raya City

bekerja memiliki risiko 2,6 kali untuk tidak memanfaatkan Posyandu dengan baik dibandingkan dengan responden yang tidak bekerja (Rita, 2016).

Pada variabel jarak, hasil penelitian ini sejalan dengan penelitian yang dilakukan Reihana, dkk (20I2) dimana jarak rumah tidak memberikan pengaruh yang signifikan antara jarak rumah yang dekat Posyandu dan jarak yang jauh dari posyandu dengan partisipasi menimbang balita ke Posyandu (Reihana, dkk, 20l2). Penelitian ini berbanding terbalik dengan hasil penelitian Idaningsih (2016) yang menyatakan bahwa ibu balita dengan akses pelayanan dalam hal ini jarak dari rumah ke tempat pelayanan posyandu yang dekat akan melakukan kunjungan balita ke posyandu 3.067 kali lebih besar dibandingkan dengan ibu balita yang akses pelayanan kesehatannya jauh.

Pada variabel usia, hasil penelitian ini berbanding terbalik dengan hasil penelitian yang dilakukan Idaningsih (2016), dimana hasil analisis menunjukan bahwa ibu balita dengan umur 20-35 tahun dan teratur melakukan kunjungan sebanyak 79.2\%, sedangkan Ibu balita dengan umur $<20$ dan $>35$ tahun dan teratur melakukan kunjungan sebanyak 54.8\%. Hasil uji statistik $p$ value $=0.014<0,05$ yang berarti ada perbedaan yang signifikan antara umur dalam kunjungan balita teratur ke posyandu. Dalam penelitian ini Idaningsih membagi usia menjadi usia berisiko ( $<20$ tahun dan $>35$ tahun) dan usia tidak berisiko (20 - 35 tahun) yang selanjutnya hasil analisis data diperoleh ibu balita dengan umur tidak beresiko (20 - 35 tahun) akan melakukan kunjungan balita ke Posyandu 3.129 kali lebih besar dibandingkan dengan lbu balita dengan umur beresiko (< 20 tahun dan $>$ 35tahun) (Idaningsih, 2016).

Banyaknya variabel tidak terikat (usia, pendidikan, pekerjaan dan jarak) yang tidak memberikan pengaruh signifikan pada kepatuhan, menurut peneliti disebabkan oleh beberapa faktor:

I) Sampel yang diambil oleh peneliti terlalu sedikit. Padahal menurut Sutopo, semakin besar jumlah sampel yang diambil maka akan semakin kecil kesalahan yang terjadi. Hal itu dikarenakan sampel yang besar akan memberikan pendugaan yang lebih mendekati nilai sesungguhnya (true value) yang diinginkan peneliti.

2) Jawaban-jawaban responden yang homogen. Variabel terikat yang diambil terlalu umum dengan jawaban yang sangat sedikit, sehingga jawaban-jawaban yang dibarikan oleh responden menjadi homogen. Untuk penelitian selanjutnya, ada baiknya peneliti menambahkan beberapa variabel lain, seperti, pengetahun, dukungan keluarga, dan lainnya.

\section{KESIMPULAN}

Dari hasil analisis univariat paling banyak ibu yang aktif memanfaatkan pelayanan di posyandu adalah ibu yang berada di rentang usia 20 - 35 tahun yaitu sebesar 55\%, pendidikan terakhir SMA yaitu sebanyak $40 \%$, ibu yang memiliki balita dan tidak bekerja $85 \%$, jarak yang terjangkau $90 \%$, dan tidak rutin melakukan kunjungan ke posyandu $87,5 \%$. Berdasarkan analisi bivariat, tidak ditemukannya variabel tidak terikat (usia, pendidikan, pekerjaan dan jarak) yang menunjukkan pengaruh terhadap pemanfaatan pelayanan posyandu.

\section{UCAPAN TERIMA KASIH}

Ucapan terima kasih kepada Politeknik Kesehatan Kemenkes Palangka Raya.

\section{REFERENSI}

I. Sugiyarti R, Aprilia V, \& Hati F.S. 2014. Kepatuhan Kunjungan Posyandu dan Status Gizi Balita di Posyandu Karangbendo Banguntapan, Bantul, Yogyakarta. Yogyakarta: Sekolah Tinggi IImu Kesehatan Alma Ata Yogyakarta. Journal Ners and Midwifery Indonesia, 2 (3): |4|-|46. 
2. Fitriani F, Hadi M, \& Atik N.S. 2016. Hubungan Tingkat Pengetahuan Ibu tentang Posyandu Balita dengan Kepatuhan lbu yang Membawa Balita ke posyandu di Desa Tumpang Krasak Kecamatan Jati Kabupaten Kudus. Kudus: AKBID Mardi Rahayu Kudus.

3. Idanigsih A. 2016. Faktor-Faktor yang Berhubungan dengan Kunjungan Balita ke Posyandu. Jurnal IImiah Indonesia 20I6; I (2); I629.

4. Dinas Kesehatan Provinsi Kalimantan Tengah. 2016. Profil kesehatan 2016 Provinsi Kalimantan Tengah. Palangkaraya: Dinas Kesehatan Provinsi Kalimantan Tengah.

5. Rita L. 2016. Faktor-Faktor yang Berhubungan dengan Pemanfaatan Posyandu pada Balita di Desa Ulak Jaya Kecamatan Sintang Kabupaten Sintang Tahun 2016. Wawasan Kesehatan, 3 (I): 68-80.

6. Kementerian Kesehatan Republik Indonesia. 2012. Buku Pegangan Kader Posyandu. Jakarta: Kementerian Kesehatan Republik Indonesia, 2012.

7. Kementerian Kesehatan Republik Indonesia. 2018. Data dan Informasi Profil Kesehatan Indonesia 2018. Jakarta: Kementerian Kesehatan Republik Indonesia.

8. Reihana \& Duarsa A.B.S. Faktor-Faktor yang Berhubungan dengan Partisipasi lbu untuk Menimbang Balita ke Posyandu. Jurnal Kedokteran Yarsi 20I2; 20 (3): I43-157 